PARECER.

\title{
O Usufruto Vidual Instituído pela Lei n. 4.121 de 27.08.1968.
}

\author{
Antônio Chaves \\ Catedrático de Direito Civil na Faculdade \\ de Direito da Universidade de São Paulo.
}

\begin{abstract}
SumárIo: 1. Exposição. 2. A Lei n.o 4.121 objetiva amparar a viúva, ainda que em detrimento dos interesses dos filhos do "de cujus". 3. O usufruto legal vitalício instituído pela Lei n.o 4.121, de 27-8-1962, é de Direito Sucessório. Doutrina. 4. Jurisprudência. 5. Poderes de administração do cônjuge usufrutuário. 6. A existência de testamento eventualmente válido em nada afeta a posição da viúva. 7. O usufruto recai sobre a quarta parte da totalidade dos bens do cônjuge falecido. 8. A matéria pode e deve ser resolvida nos próprios autos do inventário.
\end{abstract}

\section{Exposição.}

D. Anelina Silveira Costa, viúva e sem filhos, casou-se aos 14-4-1936, pelo regime de separação de bens e mediante pacto antenupcial, com Rodolfo Silva Costa, com filhos de matrimônio anterior.

Não se tratava do regime imposto por lei, uma vez que ela tinha, na ocasião, 48 anos, e ele 54, tendo ele procedido ao inventário do casal anterior, e sendo ela, na ocasião, destituída de bens materiais.

Rodolfo da Silva Costa veio a falecer em data de 28-10-1969.

Pretendem os filhos excluir D. Anelina do usufruto da quarta parte dos bens do cônjuge falecido.

Embora a letra da lei não lhes favoreça a pretensão, obtiveram pareceres favoráveis dos Professores Vicente Ráo, Agostinho Alvim e do Dr. J NetTo ARMANDo.

Houveram por bem então os eminentes advogados Drs. DELFIM Augusto de Faria e FÁbio Henrique S. de FARIA, dirigir-me consulta 
consubstanciada em cinco quesitos, que passo a reproduzir, acompanhados das respectivas elucidação e respostas.

A lei 4.121 objetiva amparar a viúva, ainda que em detrimento dos interesses dos filhos do "de cujus".

1. $O$ casamento foi precedido de pacto ante-nupcial estabelecendo que o regime seria o "da separação completa de bens, com exclusão, portanto, da comunhão já nos bens atualmente existentes, já nos porventura existentes de futuro".

No decurso, no entanto, de trinta e dois anos da mais completa e harmoniosa vida conjugal, várias doações foram feitas pelo conjuge varão $\dot{a}$ mulher.

Finalmente, ḋs vésperas de sua morte, apuseram suas impressões digitais num "testamento", que, sem razão plausível, enumera uma a uma as “liberalidades necessárias e suficientes para que desfrute uma vida digna e tranquila, pois os bens com que já praticou essas liberalidades lhe darão rendas expressivas para sua manutenção".

Admitindo-se o absurdo da sua validade, pode-se dai deduzir que, legando os bens que deixou $\dot{a}$ esposa, estivesse de qualquer maneira prejudicando os filhos?

O pacto ante-nupcial, na singeleza dos seus dispositivos, limita-se a estabelecer o regime de completa separação de bens.

Totalmente inútil, pois, e dispensável, a solenidade da escritura pública. Bastava que essas mesmas palavras ficassem consignadas no termo do casamento, para que, da comu- 
nhão ficassem excluidos "já os bens atualmente existentes, já os porventura existentes no futuro".

Para que, pois, o pacto ante-nupcial?

O casamento de viúvas com filhos maiores levanta fatalmente ciumes, zelos, divergências, conflitos, receio de motivos ocultos, de finalidades menos louváveis.

"Os móveis que incitam a um segundo matrimônio são vis razões de lucro, jamais de amor. Pela segunda vez mato o meu defunto, se o segundo esposo me beija no tálamo" (HAMLET, cena II do ato III).

Se um gênio como Shakespeare dava agasalho a noções desse teor, não pode causar surpresa que as pessoas diretamente interessadas, isto é, os herdeiros, ainda quando reconheçam a existência de um amor sincero e profundo, se sintam como que desfalcados, não apenas de uma parte do afeto, que prefeririam não compartilhar com quem era até então uma pessoa completamente estranha, mas - talvez mais acentuadamente - quereriam antes preservar de qualquer outro acesso alheio, o quinhão que lhes seria legado.

Tão generalizada é essa prevenção, que a ela não escapou o legislador lusitano e o pátrio. Em dispositivos completamente superados ainda revelam o receio de que o casamento de pessoas que, no começo do século, quando o período provável de vida era mais curto, consideravam-se de idade avançada, seria motivado não por impulsos do coração, mas pela atração exercida pela bolsa recheiada do outro cônjuge.

Não há no entanto o que recriminar na atitude de quem queira por fim a uma situação de celibato contrária à própria natureza humana, reconhecendo-se constituirem as segundas núpcias, tanto quanto as primeiras, o exercício de um direito inviolável. 
"A fé conjugal, o sentimento profundo de respeito por aquele que foi eleito participe das alegrias e das dores da nossa existência" - tivemos oportunidade de escrever - "devem manter-se inviolados enquanto dura o casamento; além desse limite não existe lei divina nem humana que possa recriminar ao cônjuge que se sente jovem ainda, por pedir a um novo liame os puríssimos afetos de que são capazes as núpcias".

Invocam os filhos de Rodolfo as doações que este teria feito à esposa, como que recriminando, no seu íntimo, embora não o façam às claras, a atitude do pai.

"Doações" não houve; mas se tivesse havido representariam modesta retribuição da dedicação e do companheirismo da esposa.

Mas não há sequer entrar em indagações dessa natureza.

A pergunta é outra: podia fazê-lo?

Por que não?

Não constituiam esses bens uma parte mínima de sua fortuna? Não cabiam com largueza dentro da sua quota disponível? Não podia dispor dessa parte toda em favor de Jacyr, ou de Lademiro, ou de Ana, ou de Maria, ou de Nilton, ou de João cada um de per si, ou de todos em conjunto? Não podia legá-la a uma instituição de caridade, a um estranho, a um inimigo mesmo?

Por que essa surpresa de que tenha feito esses proporcionalmente pequenos legados em favor da sua companheira fiel e dedicada, que, apesar de todas as conquistas amorosas do marido, soubera comportar-se com toda dignidade, colaborando no acúmulo da fortuna imensa?

Acentuamos a circunstância de que Rodolfo e Anelina podiam ter-se casado pelo regime da comunhão de bens 
para realçar uma diferença fundamental entre o regime da separação obrigatória, imposta por lei, de separação de bens, e o regime de separação meramente facultativo.

Enquanto que aquele decorre da lei, em circunstâncias específicas, nas quais o legislador pretende ver motivos de ordem pública para a sua aplicação, não admitindo, por isso mesmo, qualquer exceção à regra da não comunicação de bens, nem mesmo de doações as mais insignificantes, no segundo não existe qualquer razão plausível para uma aplicação rigorosa do afastamento dos quinhões de cada qual, que deixa de existir justamente quando, solenemente, se fez presente a morte.

Não nos percamos em divagações a respeito de matéria que não interessa ao fulcro da questão. Registremos apenas que a família de Rodolfo Silva Costa não podia fazer exceção à regra. Jacyr, Laudemiro, Ana, Maria, Nilton e João, todos filhos estimados e queridos, pessoas por demais distintas, não fugiram à regra de procurar despejar a madrasta daquilo a que tinha pleno direito, unindo-se todos contra ela, sozinha e desprotegida, para se apossarem de tudo quanto dela pudesse ser retirado.

Mas a primeiras manifestações do fenômeno não podiam escapar ao espírito clarividente e alerta de Rodolfo. Por mais que procurasse resistir, acabou também cedendo, pelo menos aparentemente, às injunções e pressões, de que outros exemplos poderiam ser mencionados.

Assim é que:

1. Casou-se pelo regime da separação de bens, quando podia perfeitamente tê-lo feito pelo da comunhão total, para o qual certamente se voltava o seu espírito generoso;

2. ${ }^{\circ}$ acedeu em fazer o pacto ante-nupcial, perfeitamente dispensável. 
Mas não é possível deixar de sorrir diante da argúcia e do espírito atilado demonstrados pelo "velho".

Ao mesmo tempo que se livrava da pressão dos filhos, filhas, genros e noras, rendendo-se aos seus "conselhos" ou instâncias, ao mesmo tempo que dava provas de ter perdido a primeira batalha, demonstrava já ter amadurecido no intimo a decisão que realizaria dentro de pouco tempo: proporcionar à esposa recursos suficientes para deitar por terra o efeito do regime voluntário de separação de bens, que havia sido pressionado a estabelecer, tornando letra morta o pacto ante-nupcial, revelando assim como era profundo e verdadeiro o seu amor por Anelina, como era absoluta a confiança que nela depositiva.

Os fatos não desmentiram suas previsões. Decorridos três decênios, seus bens proliferaram de tal maneira que vieram a somar fortuna que o colocou em $78 .^{\circ}$ lugar entre os maiores latifundiários do País, de acordo com dados divulgados pelo Instituto de Reforma Agrária.

Tinha, pois, razões sobejas para, ao mesmo tempo em que, aparentemente, concordava com os herdeiros, vasar-lhes a pretensão de deixar $\mathrm{D}$. Anelina totalmente privada de recursos, facultando-lhe meios pelos quais ela pudesse ir, paulatinamente, adquirindo bens móveis e imóveis.

Lançaram-se então os filhos à derradeira peleja; nos últimos dias de vida, aos 8-10-1969 (veio a falecer dez dias depois), quando já senil não tinha condições nem de resistir, nem de compreender o alcance do ato que lhe era atribuído, tomaram da mão de Rodolfo, que jamais havia feito um testamento anterior, e apuseram sua impressão digital em livro de escrituras públicas, no qual haviam forjado um testamento, cuidando, sem razão plausível, de enumerar um a um os bens de propriedade de D. Anelina, "impingidos" como tendo sido doados nessa ocasião, mesmo os de valor mais insignificante. 
Fizeram-no, porém, com tanta infelicidade, que engendraram um ato absolutamente nulo.

Nulo, entre outras razões, em primeiro lugar, porque aplicaram o sinal de sua mão esquerda, quando Rodolfo jamais autenticou qualquer documento com outra impressão digital senão a do polegar da mão direita.

Nulo, em segundo lugar, porque, nos termos do art. 1.633 do Código Civil, se o testador não souber ou não puder assinar o testamento público, "o oficial assim o declarará, assinando, neste caso, pelo testador, e a seu rogo, uma das testemunhas instrumentárias".

O testamento, praticamente "inexistente", é bem revelador das maquinações e enleios em que se engolfaram os filhos de Rodolfo, para privar a madastra de qualquer participação na fortuna do mesmo, até mesmo a título de usufruto.

Ainda que os bens aí especificados, isto é:

533247 ações da Refinaria e Exploração de Petróleo União S.A.;

uma casa residencial sita à Av. Sampaio Vidal, 264, em Marilia;

uma casa residencial sita à Rua 7 de setembro, 187, na mesma cidade;

um automóvel marca Willys, tipo Itamaraty, ano de fabricação 1968;

jóias diversas e Cr $\$ 48000,00$ aplicados em mútuo com garantia hipotecária, tivessem sido realmente dados por meio de testamento válido, - o que se nega terminantemente e poderá ser facilmente provado pela simples juntada das diversas escrituras de compra de épocas diferentes - legando algum bem à esposa, no exercício de um direito assegurado pelo Código Civil, dentro da parte disponível, não há quem possa vislumbrar qualquer "prejuízo" aos filhos de testador, beneficiados com a imensa fortuna por este deixada. 
Rodolfo Silva Costa faleceu quando estava em pleno vigor, há mais de sete anos, a lei 4121 , que, modificando o art. $1161, \S 1 .^{\circ}$, do Código Civil, estabeleceu o usufruto da quarta parte dos bens do cônjuge falecido, se houver filhos deste ou do casal, e da metade se não houver filhos, embora sobrevivam ascendentes, desde que o regime do casamento não seja o da comunhão universal.

Logo, tem ela direito ao usufruto da quarta parte dos bens do cônjuge falecido, enquanto durar a viuvez.

O dispositivo é de uma clareza tão ofuscante, que não admite dúvida, controvérsia ou vacilação.

Estabelece duas condições:

1. viuvez do cônjuge, o que implica na existência de anterior casamento válido;

2. que esse casamento não tenha sido realizado pelo regime da comunhão universal de bens.

Dessas premissas retira uma conclusão imperiosa, terminante, inafastável: o cônjuge sobrevivo terá direito, enquanto durar a viuvez, ao usufruto da quarta parte dos bens do parceiro falecido, variando o "quantum" na forma exposta, conforme haja ou não filhos do "de cujus" ou do casal.

Terá direito.

Não diz o dispositivo: poderá ter direito.

Não diz: ficará a critério do juiz conceder ou não o usufruto.

Não diz: o direito será reconhecido caso o cônjuge sobrevivente não possua fortuna ingente.

Não diz: na dependência da boa vontade, da condescendência ou da magnanimidade dos herdeiros.

Não diz: se for do agrado das forças armadas, de algum partido político ou do clero.

Como, pois, diante de dispositivo de clareza tão impressionante, tecer o aranhal de toda uma argumentação artificiosa, levantando-se celeuma a pretexto de imaginários, fantasticos desejos do legislador? 
Como atribuir-lhe intenção diametralmente oposta àquela que o inspirou, e que resulta à toda evidência da letra da lei?

A discussão travada nos autos, principalmente nos pareceres de juristas notáveis como os professores Vicente Ráo, Agostinho Alvim e do Dr. J. Netto Armando, de se saber se D. Anelina havia assumido algum compromisso válido de "dar a sua anuência em todas as transações de natureza civil e comercial relativos a vendas, incorporações e doações de bens imóveis pertencentes a Rodolfo Silva Costa"; se se cogitava ou não da incorporação dos seus bens imóveis em sociedade anônima; se a lei 4121 deveria ou não ser aplicada apenas aos casos em que o cônjuge falecesse sem nada deixar à esposa; se o "sentido social e humano" é deixar à míngua quem colaborou na ereção de uma verdadeira fortuna, para aquinhoar enteados gananciosos; se a intenção do "de cujus" ainda que estivesse em condições de saber se as pretensas “doações" proporcionavam ou não a D. Anelina rendas que equivalessem ou não ao usufruto legal; se ocorreria realmente a paradoxal preocupação de dispensála... dos "incômodos da situação de simples usufrutuária, que a tornariam, de um modo ou outro, sujeita aos seus enteados", não passam de desvio de raciocínio, de cortina de fumaça, com intenção de esconder uma verdade iniludivel: o texto claro, terminante, de um dispositivo legal que não dá margem a dúvida alguma em sua interpretação.

$\mathrm{E}$ o mesmo se dirá com relação a todas as demais questões de lana caprina que foram aventadas: se ela resultaria ou não por essa forma mais favorecida do que se deixada apenas a receber o benefício legal do usufruto; se era ou não intenção do testador cumprir, por antecipação, o art. $1611, \S$ único, do Código Civil, ou de que maneira dispunha o Direito Romano e de que maneira dispõem hoje em dia, os direitos francês, italiano, espanhol ou alemão; se o fato da nossa lei não ter previsto a hipótese impediria a mulher 
sobrevivente de cumular as liberalidades recebidas com o usufruto, ou, se ao contrário, exprime manifestação clara de permitir a cumulação; se a intenção atribuída ao testador, mediante liberalidades, teria sido de evitar o usufruto, ou se essa intenção não teriam sido justamente dos que mais se sentiam por ela afetados, isto é, os herdeiros; se uma senhora duas vezes viúva, com mais de setenta anos, podia cogitar da possibilidade de, mediante um terceiro matrimônio, correr o risco de ficar privada do usufruto; se um documento escandalosamente prejudicial a D. Anelina, a tal ponto que, depois de subscrito mediante captação de vontade, diante da ameaça de providências judiciais para a sua anulação foi devolvido, tornando-se, portanto, inexistente, pode produzir algum remoto efeito, jamais podendo $D$. Anelina ter-se dado "por satisfeita de todos os seus direitos relativamente ao patrimônio de seu cônjuge"; se, portanto, retirado o consentimento expresso, poderia algum tempo ser admitido seu consentimento tácito, muito ao contrário; se há ou não viabilidade das doações serem cumuladas com o usufruto legal "antecipadamente satisfeito"; se o cônjuge deve ou não herdar do cônjuge falecido; qual a natureza do direito na Espanha; se existe ou não presunção de doação em adiantamento; se a parte que coube ao cônjuge deve ou não vir à colação; se a lei 4121 se filiou ou não aos sistemas que concedem direito ao cônjuge em caráter alimentar; se o usufruto propiciado pelo $\S 10^{\circ}$ do art. 1611 incide ou não somente na quarta parte dos bens que constituem a quota disponível e dezenas de outras questões levantadas.

Todo esse castelo de cartas, todas essas construções forçadas esboroam diante de uma pergunta singela como um sorriso de criança, transparente como o sol da montanha, cristalina como água da fonte; ultrapassam todas as pretensas doações feitas a D. Anelina a quota disponível de Rodolfo? 
Ninguém ousará afirmá-lo, se considerarmos que o valor dos bens de $\mathrm{D}$. Anelina não chegam a um bilhão e meio de cruzeiros, enquanto que a fortuna deixada por Rodolfo, calculada por baixo, ultrapassa setenta bilhõès de cruzeiros.

Que a finalidade da lei seja proteger a viúva, e não os filhos do "de cujus", comprova-se, além de pela sua simples leitura, através da lição de Planıol e Ripert, Traité Elémentaire de Droit Civil, $3^{\mathrm{a}}$ ed., t. 3, p. 558 :

“A atribuição de um usufruto ao cônjuge sobrevivente apareceu como sendo o processo que melhor concilia os diversos interesses das pessoas em presença: o cônjuge, que precisa conservar pelo menos em parte os rendimentos de que ele tinha o gozo em comum com o defunto: os membros da família, que cumpre não despojar em proveito de uma outra família. Com este sistema, a totalidade da sucessão voltará um dia aos parentes do defunto.

Pode-se considerar que esta concepção está hoje superada. A composição dos patrimônios tornou-se essencialmente mutante, e a idéia da conservação dos bens numa família não passa de um anacronismo. E sobre o fundamento atual do direito sucessório que era necessário reorganizar a devolução hereditária. O círculo da família fechou-se; já indicamos a tendência do direito moderno em admitir o cônjuge sobrevivente à partilha da plena propriedade da sucessão com os herdeiros do sangue, com alguns entre eles ao menos".

Gil Costa Alvarenga, que lhe reproduz a lição em seu fundamental Usufruto Legal do Cônjuge Sobrevivente, in Rev. For., v. 224, out-dez., 1968, p. 385-388, acrescenta que, embora anacrônico, o instituto foi introduzido em nosso 
direito revestido de caráter reformatório, visando atender interesses nitidamente sociais.

"Impunha-se o amparo do cônjuge, notadamente da mulher, a quem interesses particulares ou cautelas legais haviam imposto o regime da separação de bens, no casamento. A mulher, que durante anos emprestara ao marido o calor de sua companhia e os esforços de seu trabalho, viase de repente privada até dos meios necessários à sua manutenção, ou, pelo menos, impedida de continuar gozando do padrão de vida a que já se habituara. Tal situação se apresentava particularmente injusta em não havendo herdeiros necessários do falecido, caso em que os colaterais, muitas vezes hostis ao cônjuge supérstite, agravam ainda mais a situação deste. Outras vezes, o "de cujus" era influenciado pelos colaterais no sentido de afastar o cônjuge da sucessão, pela aplicação da regra contida no art. 1725 do Código Civil".

Foi no intuito de impedir esses abusos - friza - que surgiu com a lei 4121 a regra consubstanciada no $\S 1 .^{\circ}$ do art. 1 611, do Diploma Civil.

Ora, ainda que o "testamento" pudesse ter alguma validade, ainda que seu conteúdo correspondesse às palavras nele empregadas, como é que poderiam os filhos de Rodolfo dizer-se prejudicados, quando outra coisa não pleiteia $D$. ANELINA se não ver cumprida uma lei cujo objetivo precípuo é colocar um paradeiro em atos imorais e temerários como os que eles pretendem levar a efeito? 
O usufruto legal vitalício instituido pela lei 4121 de 27-081962 é de direito sucessório. Doutrina.

2. ${ }^{\circ}$ Existe algum fundamento, mesmo remoto, pelo qual se possa inferir que o usufruto estabelecido pela nova redação dada ao art. $1611, \S 1^{\circ}$, do Código Civil seja de natureza alimentar?"

É muito importante, nestes primeiros casos que vão se apresentando ao exame da justiça, conceituar da melhor maneira possível a natureza desse direito.

Se têm razão os que afirmam que ele se reveste de particularidades que o singularizam, o que é de evidência insofismável, não se percebe por que queiram metê-lo, à força, dentro do Direito de Família, quando é no Direito Sucessório que ele encontra o seu encaixe natural e verdadeiro.

Que o usufruto dos pais sobre os bens dos filhos ache no Direito de Família seu "habitat" natural, admite-se; mas em absoluto pode-se convir em que usufruto de natureza específica como o vidual, encontre agasalho nesse ramo de direito.

É muito certo, por outro lado, que não lhe é própria a designação de usufruto, daí decorrendo, provavelmente, a confusão que, por inadvertência ou por malícia, se estabelece em torno da matéria.

Talvez a denominação, já aventada, de desfrute legal, ou outra equivalente, tivesse a vantagem de marcar bem as divisas entre dois institutos completamente distintos, pois, se ambas as expressões dizem com o gozo de frutos ou rendimentos de coisa que pertence a outrem, o usufruto comum é, na definição de Clóvis Bevilaqua, “o direito real, conferido a alguma pessoa, durante certo tempo, que autoriza a retirar, da coisa alheia, frutos e utilidades que ela produz", sendo relativo a um ou mais bens determinados, enquanto que o 
instituído pela lei 4121 tem natureza especial, a tal ponto que abrange, indistintamente, uma quarta parte ou metade dos bens do "de cujus".

Martin Wolff, Derecho de Cosas, trad. Bosch, Barcelona, v. I, p. 119, estabelecendo distinção entre o susufruto que recai sobre coisas singulares, e o desfrute legal, que incide sobre um patrimônio separado, gravando as coisas singulares que o integram somente enquanto o compõem, encarece, là p. 119, que o assim chamado usufruto sobre um patrimônio, não é, na realidade, um usufruto "sobre o patrimônio,

"mas, uma soma de direitos de usufruto sobre objetos singulares, que recai sobre este objetos..."

$\mathrm{O}$ que acontece, e que nem todos conseguiram perceber nitidamente, é que não somente semelhante desfrute legal é de direito sucessório, como, ainda, que implica em profunda alteração na sistemática desse ramo especializado.

Gil Costa Alvarenga, aceitou, em seu aludido artigo, a observação de que o usufruto legal tem seu habitat no campo do Direito de Família. Mas dá elementos preciosos para retificar sua própria opinião, quando acolhe o ensinamento de Marcel Planiol, segundo o qual a lei francesa de 9-3-1891 outorgou ao cônjuge sobrevivente direito ao usufruto sobre parte dos bens deixados pelo consorte falecido, e não apenas reconheceu simples direito a alimentos.

$\mathrm{E}$, ainda, quando reproduz a referência de Valverde $\mathrm{Y}$ Valverde a este usufruto, como sendo "legítima do cônjuge viúvo".

O Prof. Valle Ferreira, no valioso estudo Família, Regime de Bens e Relações Sucessórias, in Rev. Forense, v. 231, julho-setembro 1970 , p. 5-10, e Rev. Tribs., v. 413, março 1970 p. 14-21, considerando que o usufruto legal vitalício vale 
como verdadeiro direito de sucessão (DE PAGE, VI, 188), assinala que foram alterados princípios de direito sucessório, com modificações de ordem legítima da vocação hereditária.

"Na verdade, o cônjuge supérstite, embora sem qualquer vínculo de parentesco, concorre com os herdeiros necessários. Mesmo sem direito à plena propriedade, participa da sucessão ao lado de pessoas ligadas pelos mais estreitos laços de sangue. A herança é deferida aos herdeiros, mas, em razão do usufruto sucessório, os bens se transferem diminuídos no valor de uso".

O aludido trabalho de GIL Costa Alvarenga, em sua autoridade de procurador do Estado da Guanabara, não podia ser mais oportuno para refutar, uma a uma, as objeções que poderiam ser levantadas no que diz respeito ao imperativo legal.

Sustentando, embora menos acertadamente, data venia, o caráter alimentar do usufruto do cônjuge, mostra que o fato do patrimônio deixado ser volumoso não descaracterizaria a natureza do usufruto: "Não é a quantidade que define a obrigação alimentar, pois o princípio geral orientador da fixação do quantum pressupõe não só as necessidades do beneficiado, como também se vale dos recursos patrimoniais da pessoa obrigada (por exemplo, art. 400 do Código Civil)".

À indagação se o cônjuge sobrevivente deve considerarse herdeiro, responde afirmativamente (daí a contradição em que cai de considerar a matéria de direito de familia):

"Pura e simplesmente, ele é herdeiro legítimo, face ao que dispõe o art. 1 603, III, do Código Civil. A ordem da sucessão ali estabelecida, porém, só vigora para uma classe na ausência da classe antecedente, ou quando, por força de disposição testamentária, o colateral afasta da sucessão o 
cônjuge sobrevivente, nos termos do art. 1725 , do Código Civil.

Desde logo se conclui, sem esforço, que a regra introduzida pela lei n. $^{\circ} 4121$ pressupõe a existência de herdeiros necessários (ascendentes ou descendentes) ou pressupõe que o cônjuge sobrevivente tenha sido afastado da sucessão hereditária pela contemplação dos colaterais, pela constituição de legatários ou de herdeiros".

Raovl Soto Morejon, Es Enajenable el Usufructo Vidual, in Revista del Colégio de Abogados de La Habana, v. 12, abril-junho 1940, invoca acórdão do Tribunal Supremo da Espanha, considerando o cônjuge viúvo como herdeiro a título universal, devendo entender-se, acrescenta,

"que a quota que a lei lhe atribui tem a mesma função que a estabelecida para os filhos, que é a de criar em seu favor - exclusivamente em seu favor - uma proteção de caráter econômico, independente da vontade do testador, e a cuja proteção a lei lhe permite tanto renunciar, como transmitila mesmo a título gratuito, ou, o que é o mesmo, trocá-la por outro interesse econômico que considere mais adequado a sua necessidade - vender".

E ponto de vista externado por outros tratadistas.

Inaplicável, no entanto, ao direito pátrio, em que o usufruto legal reveste-se de todas as características que lhe dão uma natureza de direito público, e, pois, irrenunciável, a nosso ver.

Demonstra-o Valverde y Valverde:

"Deve-se levar en conta, além disso, que os usufrutos legais concedem o direito aos usufrutuá- 
rios por determinação da lei, em virtude de causas que afetam ao interesse social e não meramente privado, e não pode transmitir-se a outras pessoas em que não concorra a causa de sua outorga, pela mesma razão que o fundamento de tais usufrutos está em serem concedidos a pessoas em que somente nelas se dão os presupostos e condições legais, razão por que devem ser inalienáveis. Como se isso não fosse bastante, uma disposição legal recente nos vem a dar razão. A nova lei hipotecária revista, que permite hipotecar o direito de usufruto com as restrições que a mesma determina, diz que não se poderá hipotecar o direito de usufruto concedido pelas leis ou foros especiais aos pais ou mães sobre os bens de seus filhos e ao cônjuge sobrevivo sobre os do defunto".

Depois de referir-se a esse usufruto como sendo a "legitima do cônjuge viúvo", evidenciando assim o caráter necessário da reserva usufrutuária, acrescenta, enaltecendo a vantagem do instituto:

"se concede al viudo una cuota que le permita vivir con decoro, pués no era justo que al que compartia con su difunto causante las miserias y las satisfacciones de la vida, se le quedara en la mayor miseria al fallecimento del conyuge rico, pues como dice un autor, el superviviente forma uno de los ángulos del triágulo que representa la familia (ob. cit., tomó $\mathrm{V}, 4^{\mathrm{a}}$ ed., pag. 244).

Indaga, pouco adiante, se o cônjuge supérstite passou a ter regalias de herdeiro necessário, para responder, que "es un herdeiro "Forzoso" como los demás", residindo a única diferença "nas características da cota usufrutuária, 
que é excepcional, por recair sobre o usufruto, enquanto que as demais legítimas recaem sobre a propriedade; que é variável, porque se determina segundo hipóteses (existência ou não de descendentes); mas que é absolutamente necessária, não podendo, ser afastada pela vontade do testador".

\section{Jurisprudência.}

Se, em doutrina, a matéria pode dar margem a uma ou outra rara voz discordante, a jurisprudência pátria principalmente do E. Tribunal de Justiça do Estado de São Paulo, manifesta-se com uma unanimidade impressionante pelo reconhecimento do caráter sucessório do usufruto vidual.

A C. Terceira Câmara, num caso dessa espécie, relativo a segundas núpcias mediante regime de separação de bens, teve oportunidade de repelir a pretensão dos herdeiros que sustentavam que invocar a lei 4121 seria conferir-lhe efeito retroativo, com ofensa ao pacto nupcial celebrado muito antes.

Num verdadeiro "leading case"; reproduzida na Rev. Tribs., v. 394, agosto de 1968 , p. 165, a traçar diretriz que já se firmou, e que, aliás não poderia ser diferente, vale a pena reproduzir a argumentação do relator, des. LAFAYETTE Salles, que arrastou seus pares à unanimidade:

"Os apelantes confundem regime de bens com direito sucessório.

O regime vigora entre os cônjuges durante a vigência da sociedade conjugal.

Mas aqui não se discute ato algum patrimonial cometido durante a vida conjugal, e que acaso ponha em jogo o regime celebrado em 1948.

Os apelantes discutem sobre a extensão de seus direito hereditários. Esse, no entanto, se rege pela lei dominante ao tempo da abertura da sucessão. 
Ora, ao falecer Adriano Pereira de Andrade, já se encontrava em vigor a lei n. ${ }^{\circ} 4121$, de 1962.

Esta criou, em benefício do cônjuge, cujo regime não seja de comunhão de bens, um direito configurado pela doutrina como de legado "ex lege" (cf. Barbero, Diritto Privato Italiano, ed. 1949, p. 911; Trabucchi, Diritto Civile, ed. de 1966, p. 871, etc.).

Os apelantes não podem alegar ofensa a direito adquirido. $\mathrm{E}$ não podem alegar porque o seu direito só surgiu em 1966, quando a lei sucessória em vigor gravava a herança com um legado de usufruto em benefício da viúva.

Eis porque se nega provimento ao apclo".

Esse ven. aresto é de 22-2-1968.

Dois anos e meio decorridos, a 6-10-1970, a mesma C. Câmara, também por unanimidade, reiterou seu pronunciamento, em outro processo relativo a segundas núpcias mediante casamento de separação de bens (repertório citado, v. 422 , dezembro 1970 , p. 176).

Nesse caso, mais grave, por se tratar de regime de separação de bens obrigatório, por violação do dever de dar a inventário os bens do casal anterior, frizou o des. NóBrega DE Salles, depois de reconhecer o direito ao usufruto de parte dos bens do cônjuge falecido:

"De qualquer forma, detém a apelada por direito próprio, o imóvel do qual o apelante pretende a posse, como herdeiro, esquecido que é melhor, "si et in quantum", a posse advinda do usufruto, embora na proporção mínima acịma, porque procedente a transmissão da herança, desde que "ex lege".

Aliás, Pontes de Miranda (Comentários ao Código de Processo Givil, v. 6. ${ }^{\circ}$, p. 27), lembra 
bem que "pode-se perder o direito real de usufruto, ou de uso, ou de habitação, sem perder a posse de usufrutuário, de usuário, de habitador".

$O$ apelante percebeu muito bem em sua apelação a inocuidade de sua proteção, enquanto não resolver a questão do usufruto da apelada, tanto que se opõe a pagar $1 / 8$ do que valer o aluguel do imóvel, esquecido que tal solução não poderá ser tomada na presente ação, que versa sobre o direito que não pode exercer".

Bem expressivas as ementas dos dois acórdãos.

Do primeiro:

"O direito hereditário se rege pela lei dominante no tempo da abertura da sucessão.

A lei n. ${ }^{\circ} 4121$, de 1962 , que deu nova redação ao art. 1611 do Código Civil, criou em benefício do cônjuge sobrevivente, cujo regime não seja de comunhão de bens, um direito configurado pela doutrina, como de legado "ex lege".

Do segundo:

"A mulher casada pelo regime de separação de bens, tem direito de usufruto de parte dos bens do marido falecido, nos termos da lei n. 4121 , de 1962".

A matéria não tem levantado maiores dúvidas.

A C. Segunda Câmara do E. Tribunal de Justiça de Minas Gerais, também por unanimidade (Rev. Tribs., v. 402/373), deixou decidido:

Embora o casamento se tenha realizado, obrigatoriamente, pelo regime da separação de bens, ao cônjuge viúvo assistirả, enquanto durar a 
viuvez, o direito ao usufruto dos bens do "de cujus" pela forma e na proporção prevista na lei n. 4 121, de 1962".

Teve oportunidade de salientar o relator, des. Silvio Ceroueira, que o dispositivo, incluido no Código em razão do art. 11 da lei 4 121, consagrou um direito que a doutrina denominara de "legado ex lege", conforme Barbero (Diritto Privato Italiano, p. 911) e Thabuchi (Diritto Civile, p. 871).

Ven. acórdão unânime da C. Terceira Câmara Civil, em caso mais doloroso, porquanto os enteados claramente alegavam que a viúva teria se casado com propósito calculista, aproveitando-se da diferença de idade, por ocasião do casamento, ela com 51 e ele com 72 de idade, abandonando-o na ocasião da doença, não teve dúvida em decidir, Rev. Tribunais, v. 431, p. 88 :

"A viúva, enquanto permanecer nesse estado, tendo sido casada no regime da separação de bens, tem direito ao usufruto da quarta parte dos bens do espólio do marido".

A C. Quarta Câmara, por sua vez, também sem discrepância de votos, decidiu (Rev. citada, v. 416/143) :

"O simples fato de o "de cujus", por ser casado no regime da separação de bens, haver instituído legatário, não exclui o direito do cônjuge sobrevivente de haver usufruto dos bens, conforme dispõe expressamente o art. $1611, \S 10^{\circ}$, do Código Civil, com a redação dada pela leì n. $0^{\circ} 4121$, de 1962 , que criou o que se denomina legado "ex lege" e que independe da vontade do outro cônjuge".

Invocando precedente análogo da C. 3. ${ }^{a}$ Câmara Civil, mesmo repertório, v. 394/165, encareceu o relator, des. Médici FiLHo que "o legado "ex lege" abre verdadeira exce- 
ção à regra consagrada no art. 1692 do Código Civil,, quanto aos frutos da coisa legada, devido à própria natureza do instituto, que produz efeito de relação real".

No pano de fundo dessa tranqüila e segura unanimidade de pontos de vista, somente um acórdão, isolado, da $\mathrm{C}$. Quarta Câmara do TJ da Guanabara, com voto divergente, contrasta violentamente.

O caso é diferente do objeto da consulta, devendo, no entanto, ser considerado em pormenor, para que não ocorra o perigo de uma invocação descabida.

Em regime de separação de bens, o marido, mediante testamento, dispõe de dois imóveis, avaliados em inventário em $\operatorname{Cr} \$ 10$ 000,00, num total de $\operatorname{Cr} \$ 261$ 420,15, estabelecendo a cláusula do usufruto vitalício em favor da viúva.

O julgado não foi feliz: dividiu este montante líquido em quatro partes, considerando duas delas a parte disponível, da qual sairia o legado, e as outras duas a indisponivel, sobre a qual incidiria o usufruto legal instituído pelo art. $1611, \S 10^{\circ}$, do Código Civil.

Acolheu assim a argumentação dos filhos do "de cujus" de que ambos os legados não podiam ultrapassar um quarto do montante, nem afetar as legitimas, devendo, pois, apenas incidir na parte disponível e ter a redução traçada por esse limite de um só quarto do todo.

Contrariando a sentença certíssima de primeira instância, que havia dado razão ao cônjuge supérstite, contrariando o parecer do Dr. Procurador da Justiça, pela confirmação da mesma, tem, pelo menos sete pontos suscetíveis de crítica.

1. Considerou a hipótese como de interpretação de cláusula testamentária, quando, na verdade, nada tem a ver com ela. Já abordamos a diferença, que também é frizada, com muita propriedade, pelo voto vencido do des. Amílcar LAURINDO Ribas: 
"Uma coisa é o usufruto testamentário e outra o usufruto legal, emanando aquele de ato volitivo do proprietário, e este da determinação da lei.

Dos bens que se tenha, por conjugação dos dois permissivos, uma metade é disponível e outra indisponível, por constituir a legítima dos herdeiros.

Da disponível o proprietário usa como melhor lhe aprouver; e se lhe toca atribuí-la a terceiro por inteiro, com mais razão lhe é lícito atribuí-la à viúva, plena ou em qualquer dos seus atributos, como só o domínio ou só o usufruto, como fez.

Fê-lo incondicionada e indiscriminadamente... não se podendo, por isso mesmo, admitir fosse seu propósito esse de fazer com que o usufruto legal recaísse sobre os imóveis indicados.

Houve, ao invés, um legado puro e incondicional ou não discriminativo, só compreensível, pois, como recaindo sobre a parte disponivel, que poderia ser toda ela absorvida".

2. Entendeu que a lei 4121 não deveria ser aplicada nos casos em que o cônjuge defunto tenha tomado ele próprio providências para amparar o seu consorte, mas conhece, ao mesmo tempo, que semelhante conclusão não consta “expressamente da lei 4 121", daí deduzindo, data venia, temerariamente, com base em leis e em doutrinas alienígenas, que a lei não deveria ser aplicada nesses casos.

Ora, novamente incorremos no vício de atribuir ao legislador não apenas intenções que ele absolutamente não manifestou, mas que, ao contrário, se revelam claramente opostas, pelos antípodas, às que o inspiraram ,todas voltadas no sentido de amparar a viúva, e não os filhos de casamentos anteriores. 
3. Invoca como fundamento a lei $\mathbf{8 8 3}$, de 21 de outubro de 1949, totalmente inaplicável ao caso, por dizer respeito a matéria diferente, reconhecimento de filhos ilegitimos depois de dissolvida a sociedade conjugal, outorgandose, aí sim, só para essa hipótese, na falta de testamento, ao cônjuge casado pelo regime da separação de bens, direito à metade dos deixados pelo outro, se concorrer à sucessão exclusivamente com filhos reconhecido na forma dessa lei.

4. Considerou, consequentemente, que a intenção do legislador estaria "implícita" excluindo da vantagem o viúvo que ficou amparado pelo defunto, em conseqüência de doação ou testamento, quando já verificamos que é justamente o contrário o que ocorre, nada impedindo que cônjuge aquinhoado por testamento ou doações, venha ainda a receber o benefício que a lei entendeu outorgar-lhe, independentemente de qualquer consideração.

5. Sustenta que, ao outorgar o testamento, o testador não teria pretendido amparar sua mulher, entrando em presunções que em absoluto poderiam ter orientado para a solução do caso, imaginando que ele saberia que os recursos de que a viúva necessitaria para se manter seriam suficientes.

6. Entendeu estar patente não ter sido, com todas as letras "intenção do testador ampliar as vantagens asseguradas ao viúvo ou viúva. Não declarou, pelo menos, que o legado era feito sem prejuízo do usufruto legal da lei 4 121".

Será que é necessária uma declaração de um particular para que uma lei de ordem pública, de caráter imperativo, entre em vigor?

Argumenta muito bem o des. Amílcar Laurindo Ribas, em seu voto vencido, depois de aludir, como já vimos, ter havido um legado puro e incondicional:

"Se podia, e podia exatamente porque a lei assim o permite, é irrazoado supor-se que essa absorção da parte disponível pudesse prejudicar o usufruto legal, no todo ou em parte. 
Este vem da lei, que podendo tudo, inclusive transformar em ilimitada a liberdade limitada de testar e reduzir ou eliminar a parte indisponivel, todavia não pode por-se em choque consigo mesma, tornando indisponível aquilo que ela considera disponível.

Vindo da lei, e não do arbítrio do proprietário já por ela restringido, necessariamente teria de fazer incidir o usufruto legal na parte disponivel, única que remanesce para que opere o elenco de benefícios que ela estabelec.

É indispensável, precisamente, porque ela mesma dispõe.

E dispondo paralelamente em favor dos herdeiros e da viúva, tem-se que estabelece em favor de todos um direito sucessório, em parte gravado.

A gravação proibida, além dessa do art. 1723 do $\mathrm{CC}$, é a que faça o próprio testador.

Nunca, porém, a que emane da própria lei, qual essa do herdeiro receber domínio e a viúva o usufruto.

Escorreita a decisão, pois, pondo o legado na parte disponível e o usufruto legal na indisponivel".

7 Argumenta que sempre se teve como intocável a legítima dos herdeiros, que devem recebê-la em plena propriedade. $\mathrm{E}$ com isso, revela não somente incompreensão no que diz respeito ao espírito que orientou o legislador no que se relaciona com as providências tomadas para amparar a viúva, mas até mesmo com referência ao amplo arbítrio que ele tem de, a qualquer momento, alterar critérios superados em prol de uma proteção mais adequada da viúva do "de cujus". 
Poderes de administração do cônjuge usufrutuário.

No que diz respeito aos poderes de administração do cônjuge sobrevivente, no caso de usufruto regulado pelo $\S 10^{\circ}$ do art. 1611 , do Código Civil, convém que não se iludam os herdeiros de Rodolfo Silva Costa.

Nos termos do art. 718 do mesmo estatuto, o usufrutuário tem direito à posse, uso, administrativo e percepção dos frutos.

Quer dizer: tem direito ao uso e gozo o mais amplo possivel, ressalvada a condição de entregar intacto o bem, ou o seu equivalente, aos herdeiros, por ocasião da sua morte.

Desse dispositivo deduzia Carvalho Santos não ser lícito ao testador, legando um bem em usufruto, revogar esse preceito, privando o usufrutuário da administração, investindo nestes poderes quanto aos bens dados em usufruto a outra pessoa.

Se assim é em relação ao usufruto vonlutário - complementa Gil Costa Alvarenga - " com mais razão se aplica a regra em se tratando de usufruto legal deferido ao cônjuge sobrevivente, pelos próprios princípios que o inspiram. Mas, estando a herança ainda indivisa, a aplicação da regra deve satisfazer-se investindo o cônjuge na inventariança".

"O novo caso de usufruto legal," - conclui, depois de insistir em que o cônjuge supérstite, não sendo de comunhão universal o regime de bens, pode e deve ser o inventariante, pois é "herdeiro forçado" - "introduzido em nosso direito pela lei 4 121, deve ser interpretado tendo em mira, sempre, os interesses do cônjuge sobrevivente, que, de tão fortes, podem até comprometer os interesses mais amplos dos próprios descendentes, reformulando todo um tradicional entendimento doutrinário". 
Bem se percebe, então, que longe de ser de caráter alimentar, o usufruto criado pela lei 4121 constitui verdadeira legítima do cônjuge viúvo, com manifesta prioridade sobre os direitos hereditários dos filhos do primeiro casamento.

A existência de testamento eventualmente válido em nada afeta a posição da viuva.

“3.' Pode-se ainda deduzir que a intenção do testador tivesse sido a de deixar a totalidade da parte restante e seus bens a seus herdeiros, livre de gravames de qualquer espécie?"

Admiti-lo seria lucubração fantasiosa e estapafúrdia.

Jamais manifestou Rodolfo Silva Costa intenção, mesmo remota, de deixar sua fortuna livre de gravames ou peias.

Homem rústico, afeito ao trabalho, à luta árdua pela conquista da fortuna que acabou acumulando graças à contribuição importantíssima de D. Anelina, homem sem cultura, analfabeto mesmo, sem preparo jurídico especializado, não lhe podiam passar pelo espírito essas filigranas dos dispositivos legais.

mais do que provável, quase certo, que nem sequer sabia que uma quarta dos seus bens ficaria gravada com a cláusula de usufruto em benefício da esposa, pelo fato de ter contraído núpcias pelo regime da separação de bens.

Mas, ainda qe o soubesse: poderia tê-lo evitado?

Mil vezes não!

A lei é de caráter público, imperativo, iniludível: o cônjuge, no caso em exame, "terá direito, enquanto durar a viuvez, ao usufruto da quarta parte dos bens do cônjuge falecido". 
Essas expressões "terá direito" revelam, a todo vapor (ou, para atualizarmos a expressão, a toda força atômica), que, em absoluto, fica ao arbitrio do "de cujus" a possibilidade de escamotear esse direito da esposa, ou de qualquer maneira diminuir a sua extensão, coisa que, de resto, ele jamais faria no pleno gozo de sua consciência.

E se a lei é tão clara que a interpretação mais forçada não permite ao próprio marido contornar a vontade férrea do legislador, muito menos será dada essa oportunidade, através de subterfúgios, de malícia, a enteados cubiçosos, ingratos e mal intencionados.

Ainda que existisse testamento beneficiando D. Anelina, em nada ficaria alterada - insista-se - a posição do problema.

E mesmo Valverde y Valverde quem o assinala.

“A quota legitimária a que nos referimos, é igualmente aplicável à sucessão testada que à intestada, pois, embora o Código não o diga de modo terminante, é o mesmo que o tivesse expressado, porque se dissemos antes que o viúvo é um herdeiro legitimário como os demais, e sendo a legítima de aplicação a ambas as sucessões, é claro que a do cônjuge viúvo tem a natureza de todas. Isto não obsta que na sucessão intestada herde o viúvo a herança do defunto; o que importa consignar aqui é que a quota legitimária deve-se dar ao cônjuge viúvo, do mesmo modo na sucessão testada como na intestada, a não ser que nesta, por faltarem parentes mais próximos, seja herdeiro legítimo do defunto" (p. 248).

Reforça Gil Costa Alvarenga a argumentação, aditando que o entendimento que mais se coaduna com a finalidade da lei, é que considera legítima a parte desíinada ao cônjuge sobrevivente. 
A expressão "embora sobrevivam ascendentes do "de cujus", autoriza a concluir que o direito do cônjuge sobrevivente ao usufruto

"afirma-se até contra o direito de uma classe de herdeiros necessários. Se o cônjuge pode privar os ascendentes do uso e do gozo de uma parte dos bens, é porque o direito que ele exerce tem mais força que o direito destes herdeiros necessários. Logo, trata-se de legítima a parte que constitui o objeto do direito do mesmo cônjuge, pois não se compreenderia que um direito mais fraco neutralizasse os efeitos de um direito forte".

Assenta, em seguida, o princípio de que o direito do cônjuge deve ser preservado, quando o testador destine proporção maior a herdeiros e legatários pará satisfazer o direito do cônjuge ao usufruto, daí deduzindo que a parte sobre a qual incidirá o usufruto constitui autêntica legítima.

$\mathrm{E}$, com palavras que cabem como uma luva ao caso da consulta, conclui:

"Logo, a consequência inafastável é que os beneficiários legítimos ou instituídos, devem curvar-se à pretensão do cônjuge supérstite, que é herdeiro forçado, que pode até comprometer os interesses de herdeiros tradicionalmente considerados necessários, como no caso dos ascendentes. A solução jurídica, portanto, é a aplicação das regras constantes do art. 1727 do Código Civil, que disciplinam a redução das disposições testamentárias aos limites da porção disponível..."

E ainda no estudo do Procurador do Estado da Guanabara que iremos encontrar o mais imparcial dos pronunciamentos, para mostrar que, ainda que tivesse sido D. Anelina realmente contemplada com meia dúzia de doações, insigni- 
ficantes diante do valor do patrimônio deixado por Rodolfo Silva Costa, em nada se alteraria a situação jurídica :

"A eventualidade de o cônjuge figurar no testamento como legatário de alguns bens não invalida o direito ao usufruto da quarta parte ou da metade, conforme o caso, dos bens do "de cujus". Isto porque a vontade presumida do testador é que a seu cônjuge, além de usufruir a metade dos seus bens, deveria caber a plena propriedade de outros bens".

Indaga, então, se o cônjuge supérstite, casado sob regime que não o da comunhão universal, prefere aos colaterais ou aos herdeiros instituídos para o fim de recolher o aludido usufruto, isto é, se com o advento da lei n. 4121 passou a ter regalias de herdeiro necessário.

Chega, como é natural, a resposta afirmativa.

O usufruto recai sobre a quarta parte da totalidade dos bens do cônjuge falecido.

" $4 .^{\circ} O$ usufruto recai sobre a totalidade dos bens ou somente sobre a meação do "de cujus"?

$O$ cônjuge sobrevivente, seja qual for o regime de bens, desd̉e que não esteja desquitado, é colocado em terceiro lugar no que diz respeito à sucessão legítima.

Focalizemos apenas o regime de separação de bens, que é o que interessa ao caso da consulta.

Consigne-se o fato curioso de se ver estabelecida, praticamente, a comunhão, que é o regime preferido pelo Código, justamente quando cessa a convivência, desde que não haja nem ascendente nem descendentes do cônjuge.

$\mathrm{E}$ quando houver um desses parentes? 
Toma a lei, na impossibilidade de estabelecer aquela comunhão, três providências, destinadas, se não a melhorar a situação do supérstite, pelo menos a manter seu "status", o teor de vida a que havia sido habituado.

A primeira é, quando concorra exclusivamente com filhos adulterinos do cônjuge pré-morto, reconhecidos, atribuir-lhe o art. $3 .^{\circ}$ da lei 885 , de 21-10-1949, metade dos bens deixados pelo "de cujus" na falta de testamento.

A segunda é o usufruto da quarta parte dos bens do cônjuge falecido, instituído com o acréscimo do $\S 1^{\circ}$ ao art. 1611 do Código Civil pela aludida lei 4 121, de 27-08-1962, enquanto durar a viuvez, se houver filhos do cônjuge falecido ou do casal, o da metade se não houver filhos, embora sobrevivam ascendentes do "de cujus".

A terceira é o direito real de habitação a favor do cônjuge sobrevivente, casado sob o regime da comunhão universal, enquanto viver e permanecer viúvo, e sem prejuizo da participação que lhe caiba na herança, relativamente ao imóvel destinado à residência da família, desde que seja o único bem daquela natureza a inventariar.

Bem se percebe, assim, como é diametralmente oposta a vontade do legislador daquela que se lhe pretende atribuir de favorecimento exclusivo dos filhos, em detrimento do cônjuge que com ele batalhou pela vida durante trinta e dois anos consecutivos!

Não se trata de um rompante seu, de uma medida improvisada ao correr de influências momentâneas.

E, sim, a evolução de um pensamento longamente amadurecido, já revelado pelo dec.lei 3 200, de 19-04-1941, Lei de Proteção à Família, no amparo à brasileira casada com estrangeiro sob regime que exclua a comunhão universal, por morte do marido, mediante o usufruto vitalício da quarta parte dos bens do mesmo, se houvesse filhos brasileiros do casal, e da metade, se não os houvesse. 
O dec. 4121 outra coisa não fez senão ampliar e reforçar essa garantia em favor do cônjuge, no que agiu com inegável acerto, por favorecer quem contribuiu para a construção da fortuna, e que provavelmente se esforçará para conservá-la, de preferência a quem nada fez para amealhála, e provavelmente irá dissipá-la.

E a derradeira etapa de um sistema de proteção, atualíssima, dos nossos dias, nada valendo, pois, argumentar com legislação estrangeira e com invocação de tratadistas do século passado, nem mesmo do atual, anteriores a essa evolução completa, muito menos com princípios do Direito Romano.

Comentando o $\S 1 .^{\circ}$ do art. 1611 do Código Civil, com a nova redação, faz ver Gil Costa Alvarenga que essa conquista do direito brasileiro de há muito se instalara em outros sistemas jurídicos, considerando-a mesmo fórmula ultrapassada, por derivar da velha idéia da conservação de bens dentro de uma só família com menosprezo à função social do companherismo familiar.

Mostra, com Planiol e Ripert, que a tendência do direito moderno é admitir o cônjuge sobrevivente à partilha da plena propriedade da sucessão com os herdeiros do sangue, ou, pelo menos, com alguns deles.

Reconhece que, embora anacrônico, o instituto foi introduzido em nosso direito com caráter reformatório, procurando amparar o cônjuge, notadamente a mulher, no caso de separação de bens no casamento, imposto por interesses particulares ou cautelas legais, acrescentando:

"Decompondo-se a propriedade em seus três poderes de uso, de gozo e de disposição, concluise que, com a abertura da sucessão, transmitem-se ao cônjuge supérstite os dois primeiros, e aos herdeiros legítimos ou instituídos a nua-propriedade. 
O fato gerador é único: falecimento do cônjuge; mas os sujeitos passivos da obrigação tributária referente ao imposto de transmissão causamortis são de duas ordens: cônjuge sobrevivente, que recolhe o usufruto, e herdeiros ou legatários, que recolhem a nua-propriedade da metade dos bens deixados. Em falecendo o cônjuge sobrevivente, ou contraindo ele novas núpcias, extinguese o usufruto, e nova transmissão se opera, eis que novo fato gerador tem lugar. $\mathrm{E}$ a cada fato gerador corresponde uma tributação".

O magistrado francês L. Zeguicki, em seu Exposé des travaux préplaratoires de la loi des 9-10 mars 1891 qui imodifie les droits de l'époux sur la succession de son conjoint prédécédé. Commentaire de cette loi, in Revue Critique de. législation et de Jurisprudence, Paris, 1892, p. 93 e segs., começa assinalando a iniqüidade flagrante da redação primitiva do art. 767 do Código francês, só admitindo a sucessão do cônjuge ao prefalecido, caso este não deixasse nem parentes em graus sucessiveis nem filho natural.

"Como conceber" - indagava - "sem deplorar seus efeitos, que o cônjuge sobrevivo, depois de ter vivido no bem estar, alguns na opulência, se encontre repentinamente reduzido à mais profunda miséria, enquanto que os herdeiros naturais do defunto, que frequentemente terão nutrido enquanto vivo sentimentos de inimizade contra ele, gozarão de uma ventura não merecida, porque, surpreendido pela morte, o cônjuge prefalecido não terá tido o tempo para garantir por ato entre-vivos ou testamentário, o destino de seu cônjuge sobrevivo!"

Tesce longas considerações, demonstrando que o Código Civil foi imprevidente e duro para o cônjuge sobrevivente. 
"A dignidade do casamento, a solidariedade de duas existências unidas para fundar uma família, não poderia permitir que este vínculo seja quebrado pela morte, colocando o esposo sobrevivente numa posição precária e humilhada. Não se deve, se existem filhos, condená-lo a pedir-lhes uma pensão alimentar, e se não existem, a que viva pobre e desclassificado, ao lado de herdeiros do sangue enriquecidos. Esta questão apresenta um interesse de justiça e de moral protegido no passado e no presente pela quase universalidade das legislações".

Comentando os termos da lei francesa, cujos dispositivos levaram mais de setenta anos para serem repetidos pela lei brasileira 4 121, reproduz as criticas que lhe foram dirigidas, no sentido de que o viúvo que permanece o chefe e o elemento de ligação da família, devia ter, durante sua viuvez, uma situação análoga à que desfrutava durante a vida de seu cônjuge, sendo o usufruto de um quarto insuficiente para esse objetivo.

Reconhece que na transmissão dos bens, por via hereditária, cumpre, em primeiro lugar, colocar o interesse da conservação dos bens nas famílias. Adita logo, porém, que esse motivo não é o único a ser considerado:

"ao lado, coloca-se o da afeição presumida e, mais particularmente, aquela fundado numa regra de justiça superior, que, ao mesmo tempo que ordena ao individuo, se impõe por igual autoridade ao legislador, não como regulador, mas como intérprete das vontades do indivíduo. Investindo o esposo sobrevivente de um direito provisório sobre a sucessão de seu cônjuge, o legislador salvaguardou ao mesmo tempo o princípio da conservação dos bens em proveito dos herdeiros do sangue, e os interesses do cônjuge sobrevivo". 
Entre nós, como que se antecipando às objeções que fatalmente viriam, do gênero das que formam objeto dos autos a que é relativa a presente consulta, o prof. Valle Ferreira, em seu trabalho já mencionado, não poupa criticas, mas não abdica da sua posição imparcial, ao consignar:

"Deve ser observado que o legislador de 1962, na agitação daqueles dias, nada esclarece quanto à extensão do direito concedido ao cônjuge, de maneira que ficamos sem saber se o usufruto será exercido sobre todos os bens, ou se alcança tão somente a parte disponível.

De outro modo, é preciso lembrar que o usufruto exercido sobre a fração que a lei determina, na certa vai trazer dificuldades, principalmente quando os bens da herança consistirem em prédios rústicos, à vista de questões referentes à administração da coisa e à distribuição dos frutos.

Como se tanto não bastasse, ainda pode ser considerado que as legislações sempre se esforçaram em reduzir os casos de usufruto, que prejudicam a circulação dos bens, e, consequentemente, desvalorizam a propriedade. São desvantagens que, de certo modo, talvez possam ser corrigidas com a conversão de usufruto sucessório em renda vitalícia (art. 1 431).

Na hipótese de só se encontrarem móveis entre os bens da herança, a dívida seria da sucessão. Nesse caso, o crédito do cônjuge ficaria garantido por caução idônea, de tal forma que interesses gerais ficassem atendidos sem prejuízo do usufrutuário". 
Passando a responder ao quesito, há que observar que o art. $1611, \S 1 .^{\circ}$, dá direito ao usufruto "da quarta parte dos bens do cônjuge falecido".

Não estabelece qualquer limitação, de modo que não há motivo para levantar dúvida sobre se incide apenas sobre a meação do "de cujus": diz respeito à "quarta parte dos bens", isto é, bem claramente, à quarta parte da totalidade dos bens, não apenas da meação.

Nem poderia ser diferente a orientação que procura salvaguardar o "status" do sobrevivente, o que não ocorreria com o usufruto relativo apenas a uma oitava parte da totalidade do acervo deixado pelo cônjuge pré-morto.

A matéria pode e deve ser resolvida nos próprios autos do inventário.

" $59^{\circ} \mathrm{O}$ assunto pode ser resolvido nos próprios autos de inventário, ou configura matéria de alta indagação"?

Nos termos do art. 466 do Código de Processo Civil. "O juiz poderá decidir, no inventário, quaisquer questões de direito e de fato fundados em prova documental inequívoca, remetendo para as vias ordinárias as que exigirem maior indagação".

Matéria de alta indagação - dissertam os doutrinadores - é aquela que não pode ser solucionada com os elementos constantes dos próprios autos, sendo necessário proceder a estudos e verificações que exigem o debate e a prova que só uma ação ordinária podem proporcionar, pela comodidade e vagar que lhe são próprios.

Ou, como quer Carlos Maximiliano: "Tem-se como de alta indagação não as questões puramente de direito, ou as que podem ser provadas por documentos exibidos pelas partes; mas, sim, as que não prescindem, para sua solução, 
do auxílio de outros elementos, como testemunho, vistoria, arbitramento, depoimento da parte, exame demorado de provas, debate esclarecedor entre os interessados".

Que a matéria não é de alta indagação, devendo, pois, ser resolvida nos próprios autos do inventário, resulta da jurisprudência tranqüila dos nossos tribunais, que têm sempre resolvido a matéria nos próprios autos do inventário, como se verifica nos julgados recolhidos pela Rev. dos Tris., v. $431 / 88,416 / 143,402 / 373,394 / 165$, etc.

Consigna mesmo o penúltimo acórdão, do Tribunal de Justiça de Minas Gerais:

"Trata-se de pura questão de direito, perfeitamente solucionável no processo de inventário, pois não é daquelas de tal forma intrincadas, que dependem de larga discussão para serem justa e convenientemente resolvidas".

E o ven. acórdão citado, Rev. Tribs. 431/88, assinalou, pelo voto do relator, MEdeiros Junion, que a viúva havia comprovado documentalmente as condições exigidas por lei, para que auferisse do benefício do usufruto:

"Tanto basta para que este lhe seja conferido na partilha. A apelada é titular de um benefício restrito e condicionado à sua permanência no estado de viuvez. Como tal, está incluída no capítulo próprio do Código Civil, que trata da ordem da vocação hereditária. E sua exclusão não podia ser obtida pela forma simplista de omiti-la no termo do inventário ou declarações do inventariante".

A orientação já é tradicional.

Acórdão coletado no mesmo repertório, v. 188/411 decidiu : 
"Como questões de alta indagação insucetíveis de apreciação em inventário, não podem ser consideradas as de direito, por mais intrincadas que sejam, e as de fato quando fundadas em documentos, questões em última análise que não dependem de prova "aliunde".

Como exemplos de questões puramente de direito, que nossos tribunais exigiram fossem resolvidas nos próprios autos, podem ser apontados: regime de separação obrigatória de bens, no caso de casamento de varão maior de sessenta anos, Rev. Tribs., v. 163/290); saber se o filho adotivo se considera descendente, a fim de recolher bens em fideicomisso (Rev. Tribs., v. 156/545), etc.

Tratando-se, no caso, de simples aplicação de texto expresso de lei, claro e insofismável, não há dúvida que a matéria será resolvida no local que lhe é próprio, isto é, nos autos de inventário.

A maneira acertada de efetuar o cálculo é nos moldes de que dá notícia a sentença, tão injustamente reformada, a que já aludimos, conforme acórdão que se encontra à Rev. Tribs., v. 437, p. 204: deduzir-se previamente do monte, como dívida da herança, o valor do usufruto legal em favor da viúva. $O$ remanescente seria dividido em duas pares, uma das quais constituiria a legítima dos herdeiros necessários.

Nem existe outro critério plausível, uma vez que é decorrente do texto expresso de lei.

$\mathrm{E}$ os herdeiros filhos, por ocasião da morte da viúva, entrarão sem mais no gozo do direito completo, sofrendo apenas o desfalque, durante alguns poucos anos de sobrevivência, do usufruto em favor da madrasta.

Em seu Traité de Droit Civil d'aprés le Traité de Planiol, Georges Ripert e Jean Boulanger, Librairie Générale, Paris, t. IV, 1959, dissertam minuciosamente, ás p. 563 e segs., a respeito do cálculo e exercício do usufruto, fazendo ver que 
a natureza especial do direito do cônjuge sobrevivo exige um modo especial de cálculo, e impõe, ao mesmo tempo, uma distinção essencial entre o modo de cálculo e a modalidade de exercício do usufruto.

"Se o direito do cônjuge fosse um direito hereditário como os demais, a lei não precisaria preocupar-se da maneira pela qual ele deve ser calculado. As regras que determinam a devolução sucessória não precisam determinar de que elementos se compõe o total do que o direito de cada herdeiro não é senão uma quota. Quando um herdeiro tem direito à terça ou à quarta parte, é claro que se trata do terço ou do quarto da sucessão. São as regras da partilha que indicam como se forma a massa de sucessões: aos bens existentes, encontram-se reunidas as relações de que cada herdeiro está, nessa qualidade, obrigado para com os outros, quando ele tenha recebido uma doação do "de cujus".

Mas o direito do cônjuge tem um caráter que lhe é próprio: é um direito hereditário, por quanto retira sua origem da abertura da sucessão: o cônjuge não faz parte do grupo de herdeiros, ele é admitido a reclamar dos herdeiros uma certa quota em usufruto; se ele está em condições de reclamar a partilha, é em razão do caráter universal de seu usufruto. Não era portanto suficiente fixar a quota de seu direito, cumpria ainda determinar essa quota sobre um conjunto de bens hereditários. A lei ainda previu o estabelecimento de uma massa de cálculo do usufruto".

Rematam os professores da Faculdade de Direito de Paris, que esse usufruto constitui uma vantagem legal destinada a tomar o lugar de uma liberalidade que o "de cujus" 
teria podido fazer, sem comprometer em nada o destino da liberalidades efetivamente consentidas aos herdeiros, nem, com mais forte razão, o direito que os herdeiros podem ter a uma reserva.

\section{Conclusão.}

O caso da consulta é uma eloqüente demonstração de quão cauteloso e previdente foi o legislador, ao estender a sua mão à viúva de casamento sob o regime de separação de bens.

D. Anelina nada mais pretende senão continuar desfrutando uma parcela, ao menos, dos bens que tanto contribuiu para amealhar.

Com setenta anos de idade, alquebrada pelas vicissitudes da vida, desiludida e desencantada pela ingratidão dos que lhe deveriam par apoio e compreensão, se não amor, quantos anos terá ainda de existência? Cinco? Dez, no máximo?

Não poderão os filhos, genros e noras de Rodolfo sopitar por tão escasso tempo sua sofreguidão de entrar na posse dos bens cuja propriedade já é deles, e que, portanto, sabem perfeitamente irão intactos para as suas mãos?

Para os que não tenham a hombridade de fazê-lo espontaneamente, aí está o mandamento terminante da lei.

E não há juiz ou tribunal que, bem esclarecido, não se curve prazerosamente à sua determinação, de tão profunda significação moral, de tão confortador, comovente mesmo, calor humano.

São Paulo, 26 de setembro de 1972. 